\title{
PERANCANGAN SISTEM AKUNTANSI PENJUALAN TUNAI TERKOMPUTERISASI PADA AL ISHBA KARPET
}

Oleh:

ANGKI WICAKSONO

NIM.08412144016

(angkiblabalbla@yahoo.com)

\begin{abstract}
ABSTRAK
Penelitian ini bertujuan untuk (1) Mengetahui sistem akuntansi penjualan tunai yang diterapkan pada Al Ishba Karpet, (2) Merancang sistem akuntansi penjualan tunai terkomputerisasi yang sesuai dengan kebutuhan Al Ishba Karpet.

Penelitian ini termasuk ke dalam jenis penelitian pengembangan. Subjek penelitian ini adalah Al Ishba Karpet, sedangkan objek penelitian adalah sistem akuntansi penjualan tunai yang ada pada $\mathrm{Al}$ Ishba Karpet. Teknik pengumpulan data dilakukan dengan wawancara dan dokumentasi. Pengembangan sistem menggunakan metode System Development Life Cycle (SDLC). Analisis sistem menggunakan analisis PIECES, analisis kebutuhan sistem, dan analisis kelayakan sistem. Analisis kelayakan sistem menggunakan analisis kelayakan teknik, operasional, ekonomi, dan hukum. Pada tahap perancangan sistem dilakukan pemodelan data, pemodelan proses, serta desain antar muka. Tahap implementasi menggunakan metode konversi paralel.

Hasil dari penelitian ini menunjukkan bahwa sistem akuntansi penjualan tunai yang diterapkan $\mathrm{Al}$ Ishba Karpet meliputi: (1) Fungsi yang terkait dengan sistem akuntansi penjualan tunai di Al

kas, prosedur penyerahan barang, dan prosedur pencatatan penjualan. (5) Bagan alir sistem akuntansi penjualan tunai terdiri dari dua fungsi, yaitu fungsi penjualan dan fungsi gudang. (6) Sistem pengendalian intern pada Al Ishba Karpet masih belum efektif karena masih ada perangkapan tugas dalam menjalankan aktifitas perusahaan. Berdasarkan analisis PIECES, sistem yang baru memberi keuntungan dan manfaat lebih besar dari sistem yang lama. Berdasarkan analisis kebutuhan sistem, kebutuhan untuk mengembangkan sistem baru dapat dipenuhi baik secara fungsional maupun non fungsional. Berdasarkan analisis kelayakan sistem, sistem ini layak secara teknis, operasional, ekonomi, dan hukum. Desain sistem akuntansi penjualan tunai yang dirancang terdiri dari lima tabel, delapan form dan tiga laporan. Implementasi sistem akuntansi penjualan tunai terkomputerisasi menunjukkan bahwa sistem dapat berjalan baik. Sistem yang dirancang mempermudah perusahaan dalam mengolah transaksi penjualan dan meminimalisir kesalahan yang dilakukan oleh manusia. Keterbatasan sistem yang dirancang yaitu sistem tersebut hanya bisa diterapkan pada perusahaan Al Ishba Karpet saja, karena disesuaikan dengan kondisi perusahaan tersebut.
\end{abstract} Ishba Karpet adalah fungsi penjualan dan fungsi gudang. (2) Dokumen yang terkait berupa nota. (3) Catatan yang terkait menggunakan catatan penjualan. (4) Prosedur sistem penjualan tunai adalah prosedur order penjualan, prosedur penerimaan
Kata Kunci : penjualan tunai, terkomputerisasi, karpet 


\section{Jurnal Nominal / Volume I Nomor I / Tahun 2012}

\section{A. PENDAHULUAN}

\section{Latar Belakang Masalah}

Pencatatan transaksi penjualan tunai yang dilakukan menggunakan bantuan perangkat lunak lebih mudah dibanding dengan dilakukan secara manual. Oleh karena itu, sistem akuntansi penjualan tunai yang digunakan haruslah memenuhi syarat sebagai sistem yang baik agar dapat mempercepat dalam mencatat, menyimpan, mengolah, serta menghasilkan data berupa laporan yang dibutuhkan perusahaan.

Al Ishba Karpet merupakan perusahaan yang bergerak di bidang perdagangan, menjual berbagai macam jenis karpet. Al Ishba Karpet masih menggunakan sistem manual pada seluruh kegiatan usahanya dan dikelola oleh pemilik usaha sendiri. Dalam melakukan transaksi penjualan, pemilik masih terkendala pada pencatatan transaksi penjualan, terutama penjualan tunai, karena transaksi dicatat secara manual, sehingga menyebabkan kendala dalam hal ketepatan waktu, yang berkaitan dengan pengelolaan data, serta efisiensi dalam kinerja perusahaan.

Pencatatan secara manual menyebabkan terjadinya keterlambatan dalam pengelolaan data penjualan, hal ini menyebabkan terhambatnya penyampaian laporan penjualan kepada pimpinan. Jika hal ini dibiarkan maka akan membuat kinerja perusahaan menjadi tidak efisien karena sering terjadi keterlambatan pengelolaan data penjualan. Pengelolaan data transaksi penjualan merupakan hal yang penting dalam kegiatan perusahaan sehingga membutuhkan suatu sistem akuntansi khususnya yang berkaitan dengan penjualan yang dapat melakukan fungsi-fungsi pengelolaan data yang berkaitan dengan penjualan secara efektif dan efisien. Proses pengelolaan data masih dilakukan dengan sistem manual yang masih sederhana, menyebabkan informasi yang dihasilkan kurang akurat karena masih ada kemungkinan kesalahan yang terjadi dalam melakukan proses pengelolaan data penjualan tersebut.

Untuk mengatasi masalah yang timbul tersebut dibutuhkan sistem penjualan tunai yang terkomputerisasi. Oleh karena itu, akan dirancang suatu sistem penjualan tunai terkomputerisasi yang mudah digunakan dan dikelola oleh pemilik perusahaan. Sistem yang akan dirancang ini diharapkan dapat meningkatkan kinerja perusahaan Al Ishba Karpet sehingga dapat menanggulangi kesalahankesalahan yang masih sering terjadi dalam hal pencatatan transaksi penjualan, salah satu solusinya adalah penggunaan sistem akuntansi yang terkomputerisasi.

Berdasarkan uraian diatas, maka menarik minat penulis untuk mengajukan judul

"Perancangan Sistem Akuntansi Penjualan Tunai Terkomputerisasi Pada Al Ishba Karpet”.

\section{Tujuan Penelitian}

1. Untuk mengetahui sistem akuntansi penjualan tunai yang selama ini diterapkan pada Al Ishba Karpet.

2. Untuk merancang sistem akuntansi penjualan tunai terkomputerisasi yang sesuai dan layak diterapkan Al Ishba Karpet. 


\section{Jurnal Nominal / Volume I Nomor I / Tahun 2012}

\section{B. PEMBAHASAN}

1) Perancangan Sistem Akuntansi Penjualan Tunai Terkomputerisasi

Perancangan sistem akuntansi penjualan tunai terkomputerisasi adalah proses penyusunan suatu sistem akuntansi penjualan tunai menggunakan komputer. Pengolahan data transaksi penjualan tunai dilakukan menggunakan komputer yang berguna untuk mempercepat dalam mengolah data transaksi dibandingkan secara manual. Penggunaan komputer diharapkan dapat bermanfaat dalam pengolahan data transaksi penjualan tunai dalam hal memperoleh informasi secara cepat dan akurat.

2) Desain Program dalam Perancangan Sistem Akuntansi Penjualan Tunai Terkomputerisasi

Perancangan sistem akuntansi penjualan tunai terkomputerisasi digunakan untuk memudahkan pengolahan data transaksi penjualan tunai, setelah diolah diharapkan dapat memberikan informasi yang dibutuhkan untuk perusahaan. Perancangan sistem akuntansi penjualan tunai terkomputerisasi meliputi tiga desain, yaitu desain input, desain output, dan desain database.

1. Desain Input

Data yang digunakan dimasukkan ke dalam program yang digunakan untuk menghasilkan output berupa laporan bagi perusahaan.

\section{Desain Output}

Diperoleh dari input yang telah dimasukkan dan diharapkan menghasilkan laporan yang dibutuhkan oleh perusahaan.

\section{Desain Database}

Desain database merupakan proses merancang ba- sis data sebagai tempat masukan data yang kemudian akan diolah sehingga dapat menghasilkan informasi yang dibutuhkan perusahaan.

3) Implementasi Sistem Akuntansi Penjualan Tunai Terkomputerisasi

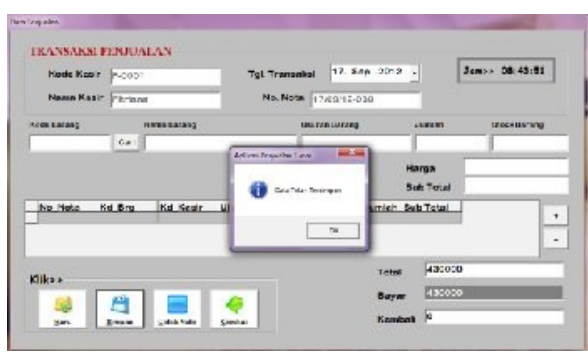

Gambar 1. Pengujian simpan data transaksi penjualan

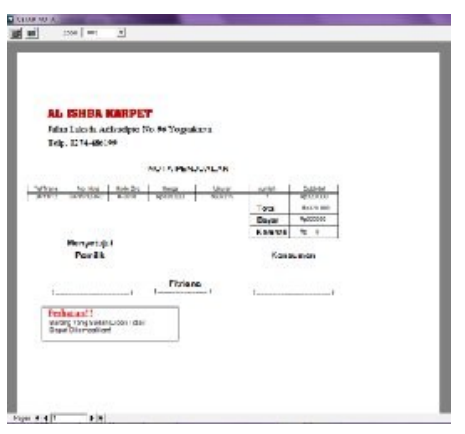

Gambar 2. Pengujian cetak nota penjualan

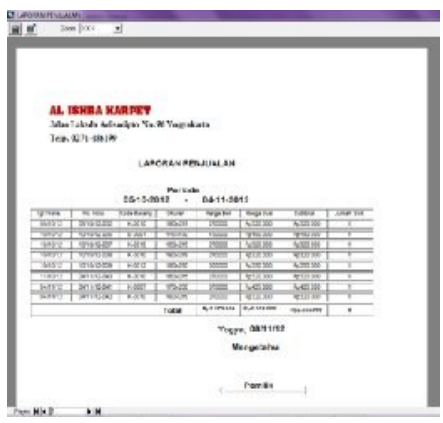

Gambar 3. Pengujian cetak laporan penjualan

\section{PENUTUP}

\section{Kesimpulan}

Berdasarkan penelitian yang dilakukan pada $\mathrm{Al}$ Ishba Karpet mengenai perancangan sistem akuntansi penjualan tunai terkomputerisasi dapat diambil kesimpulan bahwa: 


\section{Jurnal Nominal / Volume I Nomor I / Tahun 2012}

1. Sistem akuntansi penjualan tunai yang diterapkan pada Al Ishba Karpet masih bersifat manual. Hal ini dapat dilihat dari unsur-unsur sistem akuntansi penjualan tunai yang diterapkan pada $\mathrm{Al}$ Ishba Karpet.

2. Perancangan sistem akuntansi penjualan tunai terkomputerisasi pada Al Ishba Karpet dilakukan melalui tiga tahap, yaitu analisis, desain, dan implementasi.

a. Tahap analisis meliputi analisis pendahuluan dan analisis sistem. Hasil analisis system menyatakan bahwa pengembangan sistem akuntansi penjualan tunai terkomputerisasi pada $\mathrm{Al}$ Ishba Karpet layak dilakukan. Hasil analisis PIECES (Performance, Informatiton, Economy, Control, Efficiency, and Service), sistem akuntansi penjualan tunai terkomputerisasi memberikan banyak manfaat dan keuntungan bagi perusahaan dibandingkan dengan penggunaan sistem lama. Berdasarkan analisis kebutuhan sistem, kebutuhan pengembangan sistem dapat terpenuhi baik secara fungsional maupun non fungsional. Sedangkan berdasarkan analisis kelayakan sistem bahwa sistem baru tersebut layak dikembangkan baik secara teknik, operasional, ekonomi, dan legal.

b. Desain sistem meliputi pemodelan data, pemodelan proses, dan desain antarmuka. Desain sistem dikembangkan menggunakan aplikasi Microsoft Visual Basic 6.0 untuk desain antarmuka, sedangkan untuk basis datanya menggunakan aplikasi Microsoft Access 2003. Sistem akuntansi penjualan tunai yang dirancang terdiri dari lima tabel, delapan form, dan tiga laporan. Tabel yang dirancang meliputi tabel login, tabel kasir, tabel master barang, tabel master penjualan, dan tabel detail penjualan. Form yang dirancang meliputi form login, form utama, form kasir, form master barang, form transaksi penjualan, form laporan penjualan, form laporan penerimaan kas, form laporan persediaan barang, dan form ganti password. Sedangkan laporan yang dirancang meliputi laporan persediaan barang, laporan penjualan, dan laporan penerimaan kas.

c. Implementasi sistem meliputi pemilihan dan pelatihan personil, pemilihan tempat dan instalasi sistem, pengujian sistem, dan konversi sistem. Konversi yang dipilih adalah konversi paralel. Implementasi sistem akuntansi penjualan tunai terkomputerisasi menunjukkan bahwa sistem dapat berjalan baik. Sistem tersebut dapat menyimpan data-data yang telah diinput, setelah itu dapat ditampilkan kembali tanpa kesulitan mencari data yang sudah diinput tersebut. Sistem yang dirancang mempermudah perusahaan dalam mengolah transaksi penjualan dan meminimalisir kesalahan yang dilakukan oleh manusia. Kelemahan dari sistem adalah perancangan hanya digunakan untuk proses penjualan tunai pada Al Ishba Karpet, tidak bisa digunakan untuk mengolah proses yang lainnya.

\section{DAFTAR PUSTAKA}

Hanif Al Fatta.2007.Analisis dan Perancangan Sistem Informasi.Yogyakarta: Andi Offset

Jeffery L. Whitten, Lonnie D. Bentley dkk.2004.Metode Desain dan Analisis Sistem.Yogyakarta: Andi

Jogiyanto.1996.Analisa dan Desain Sistem Informasi.Yogyakarta: Andi Offset Mulyadi.2001.Sistem Akuntansi, Edisi ke-3.Yogyakarta: Salemba Empat

Nugroho Widjajanto.2001.Sistem Informasi 